\title{
Rubrobacter taiwanensis sp. nov., a novel thermophilic, radiation-resistant species isolated from hot springs
}

\author{
Correspondence \\ San-San Tsay \\ sstsay@ntu.edu.tw
}

\author{
Mao-Yen Chen, ${ }^{1}$ Shih-Hsiung Wu, ${ }^{1,2}$ Guang-Huey Lin, ${ }^{3}$ Chun-Ping Lu, ${ }^{2}$ \\ Yung-Ting Lin, ${ }^{4}$ Wen-Chang Chang ${ }^{1,2} \dagger$ and San-San Tsay ${ }^{4} \dagger$ \\ ${ }^{1}$ Institute of Biological Chemistry, Academia Sinica, 115 Taipei, Taiwan \\ ${ }^{2,4}$ Institute of Biochemical Sciences ${ }^{2}$ and Institute of Plant Biology ${ }^{4}$, National Taiwan University, \\ 106 Taipei, Taiwan \\ ${ }^{3}$ Department of Microbiology, Tzu Chi University, 970 Hualien, Taiwan
}

Alternative pre-treatment methods, such as physical or chemical treatments, are necessary in many cases to isolate samples of minor microbial populations from hot springs. For example, Rubrobacter radiotolerans (Suzuki et al., 1988), formerly named Arthrobacter radiotolerans (Yoshinaka et al., 1973), was isolated from a hot spring in Japan after water samples were irradiated with gamma-rays. Rubrobacter xylanophilus, the second validly named species of the genus Rubrobacter, was recovered, without prior gammairradiation, from the thermally polluted run-off of a carpet factory in the UK (Carreto et al., 1996). Although strains of $R$. xylanophilus and $R$. radiotolerans were isolated by different methods, both strains exhibited novel characteristics and survived extreme gamma-radiation. Other radiation-resistant bacteria, such as members of the wellknown genus Deinococcus (Deinococcus radiodurans, Deinococcus geothermalis and Deinococcus murrayi), can survive extreme irradiation (Yoshinaka et al., 1973; Ferreira et al., 1997, 1999): D. radiodurans was isolated from irradiated

Published online ahead of print on 16 April 2004 as DOI 10.1099/ ijs.0.63109-0.

tSan-San Tsay and Wen-Chang Chang contributed equally to this work. The GenBank/EMBL/DDBJ accession numbers for the 16S rRNA gene sequences of strains LS-293 ${ }^{\top}$ and LS-286 are AF465803 and AF479791, respectively.

Images produced using scanning electron microscopy and atomic-force microscopy are available, together with $\mathrm{pH}$ and salinity data and fatty acid profiles, as supplementary material in IJSEM Online. cans whereas D. geothermalis and D. murrayi were isolated from geothermal areas. In previous studies, the numbers of radiation-resistant bacteria isolated without irradiating the samples reveals that the extreme radiation resistance of the organisms is not a result of selection by irradiation, but is instead an inherent characteristic of these microbes (Sanders \& Maxcy, 1979; Ferreira et al., 1999).

In this study, two pink-pigmented, thermophilic isolates from natural hot springs in the Lu-shan area of Taiwan were isolated from non-irradiated samples from hot springs, and were similar to species of the genus Rubrobacter in various morphological, physiological, biochemical, cellular and chemotaxonomic characteristics. These isolates, strains LS-286 and LS-293 ${ }^{\mathrm{T}}$, exhibited unusual fatty acid compositions and extreme resistance to gamma-radiation.

Samples of water, thermally heated soil and mud were collected from hot springs in the Lu-shan area, Nantou, Taiwan. Aliquots $(100 \mu \mathrm{l})$ of untreated water samples were spread directly onto Thermus agar plates (Williams \& da Costa, 1992), which were subsequently sealed in plastic bags and incubated at $50{ }^{\circ} \mathrm{C}$ for 7 days. Pink-pigmented colonies were picked from the plates and subcultured for isolation of pure clones. Strains LS- $293^{\mathrm{T}}$ and LS-286 and other isolates were preserved at $-70{ }^{\circ} \mathrm{C}$ in Thermus medium containing $15 \%(\mathrm{v} / \mathrm{v})$ glycerol.

A Zeiss Axioscop light microscope equipped with a Nikon Coolpix 990 digital camera was employed to obtain 
photomicrographs. For transmission electron microscopy, bacterial strains were grown for $48 \mathrm{~h}$ and then washed using water with centrifugation. For negative-staining, $5 \mu \mathrm{l}$ liquid culture was dropped onto Formvar/carbon-coated grids (300 mesh) and stained with $1 \%$ phosphotungstic acid (w/v, $\mathrm{pH} 7 \cdot 0$ ). Electron micrographs were generated with a Hitachi model H7100 electron microscope as described previously (Chen et al., 2002a, b). Living bacterial cells were fixed to the glass slide with $0.01 \%(\mathrm{w} / \mathrm{v})$ poly-L-lysine solution and all experiments were conducted using a Solver Bio atomic-force microscope (NT-MDT). Standard procedures for atomic-force microscopy imaging were used, as described by Hansma \& Hoh (1994). Silicon nitrite tips were used, with a constant force of $5.5 \mathrm{~kg}$. Atomic-force microscopy images were generated at line frequencies between 2 and $3 \mathrm{~Hz}$, with 256 lines per image. Images were obtained using semi-contact (tapping)-mode atomicforce microscopy, at a resonant frequency of $147 \cdot 78 \mathrm{kHz}$.

Biochemical and tolerance tests were performed on isolates LS-286 and LS- $293^{\mathrm{T}}$ and on type strains $R$. xylanophilus DSM $9441^{\mathrm{T}}$ and $R$. radiotolerans DSM $5868^{\mathrm{T}}$, as described previously (Santos et al., 1989; Manaia \& da Costa, 1991; Tenreiro et al., 1995) in Thermus medium or on Thermus agar incubated at appropriate temperatures for 3 days. Media with different $\mathrm{pH}$ values and $\mathrm{NaCl}$ concentrations were prepared using appropriate biological buffers (Chung et al., 1997). Filter-sterilized carbon sources $\left(2 \cdot 0 \mathrm{~g} \mathrm{l}^{-1}\right)$, ammonium sulfate $\left(0.5 \mathrm{~g} \mathrm{l}^{-1}\right)$ and yeast extract $\left(0 \cdot 2 \mathrm{~g} \mathrm{l}^{-1}\right)$ were added to Thermus basal salts to perform singlecarbon-source assimilation tests. The growth rate was determined by measuring the turbidity $(660 \mathrm{~nm})$ of liquid cultures. Positive and negative control cultures were grown in Thermus and minimal media, respectively. All growth experiments were performed in triplicate.

The protocols used to evaluate radiation resistance were as described in previous studies (Carreto et al., 1996; Ferreira et al., 1997). Bacteria were grown in Thermus medium until they entered the exponential growth phase; they were then washed once in $0.067 \mathrm{M}$ potassium phosphate buffer $\left(\mathrm{pH} \mathrm{7 \cdot 0)}\right.$ with centrifugation at $4{ }^{\circ} \mathrm{C}$ and resuspended to a concentration of $1 \times 10^{7}$ to $1 \times 10^{8}$ c.f.u. $\mathrm{ml}^{-1}$ in $0.067 \mathrm{M}$ potassium phosphate buffer at $\mathrm{pH} 7 \cdot 0$. The suspensions were divided into $2 \mathrm{ml}$ aliquots and exposed to a ${ }^{60} \mathrm{Co}$

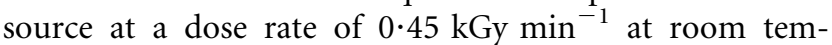
perature $\left(1 \mathrm{kGy}=10^{5} \mathrm{rads}\right)$. The gamma-radiation doses were from zero to $18 \cdot 0 \mathrm{kGy}$, in steps of $2 \cdot 0 \mathrm{kGy}$. Treated samples were diluted with the same buffer in suspensions, and $100 \mu \mathrm{l}$ each suspension was plated, in triplicate, on Thermus agar at the optimum temperatures for each strain. Colony-forming units were counted daily for up to 15 days. The viability of irradiated cells was evaluated using unirradiated suspensions of each strain under the same conditions.

The cultures used for fatty acid analyses were grown in Thermus medium at $37^{\circ} \mathrm{C}$ ( $R$. radiotolerans), $45^{\circ} \mathrm{C}$ (all strains tested) or $60^{\circ} \mathrm{C}$ (all strains except $R$. radiotolerans) until they reached the middle of the exponential phase of growth. Fatty acid methyl esters were obtained from freezedried biomass by saponification, methylation and extraction, as described previously (Kuykendall et al., 1988). Picolinyl esters were prepared according to the method described by Harvey (1982), as modified by Wait \& Hudson (1985). Fatty acid methyl esters and fatty acid picolinyl esters were separated and analysed by GC/MS, using an HP 6890 gas chromatograph fitted with a $5 \%(\mathrm{v} / \mathrm{v})$ phenylmethyl siloxane capillary column $(30 \mathrm{~m} \times 0.25 \mathrm{~mm}$; Hewlett Packard 5MS) and equipped with an HP 5973 mass-selective detector. The fatty acid methyl esters and picolinyl esters were identified and quantified and numerically analysed by using standard MIS Library Generation software (Microbial ID) as described previously (Chen et al., 2002b).

The G + C content of the DNA was obtained by HPLC, as described by Mesbah \& Whitman (1989). Bacterial DNA was isolated using a Qiagen DNAeasy tissue kit; $\lambda$ phage DNA was used as a control. DNA-DNA hybridization was performed by using a modification of the microplate method described in previous studies (Ezaki et al., 1989; Willems et al., 2001). PCR-mediated amplification of bacterial 16S rRNA genes and sequencing of the purified PCR products were performed according to Rainey et al. (1996). The 16S rRNA gene sequences of the two novel strains were compared with those in the EMBL database (Maidak et al., 1994), using FASTA (Pearson \& Lipman, 1988). The 16S rRNA gene sequences of the species most closely related to the two novel strains were retrieved from the database and all of the sequences were aligned using the CLUSTAL W program (Thompson et al., 1994) that is included in the BioEdit software package (version 5.0.6; Hall, 1999). Evolutionary distances were calculated according to the algorithm of Jukes \& Cantor (1969). The phylogenetic dendrogram was generated from evolutionary distances by using the neighbour-joining method (Saitou \& Nei, 1987), with the MEGA software package (version 2.1; Kumar et al., 2001).

Two novel pink-pigmented isolates, LS-286 and LS-293 ${ }^{\mathrm{T}}$, were isolated and selected for further studies. Cells of strains LS-286 and LS-293 ${ }^{\mathrm{T}}$ were Gram-positive. Colonies were pink in colour (when grown at $45^{\circ} \mathrm{C}$ ) or light pink in colour (at $60^{\circ} \mathrm{C}$ ) on the surface of the Thermus agar plates. In liquid culture, cells often grew in chains that were wrapped around each other, forming large aggregates. Transmission electron microscopy with negative staining revealed that the morphology of strains LS-286 and LS- $293^{\mathrm{T}}$ was pleomorphic, with short rod-shaped or coccoid cells approximately $0.9-1.0 \mu \mathrm{m}$ in diameter and $1.0-3.0 \mu \mathrm{m}$ in length, although much longer cells were occasionally observed in fresh cultures. Motility and endospores were not observed under phase-contrast microscopy. Flagella were not observed under transmission electron microscopy. In liquid culture, under transmission electron microscopy and atomic-force microscopy, cells presumably at a stage preceding cellular 


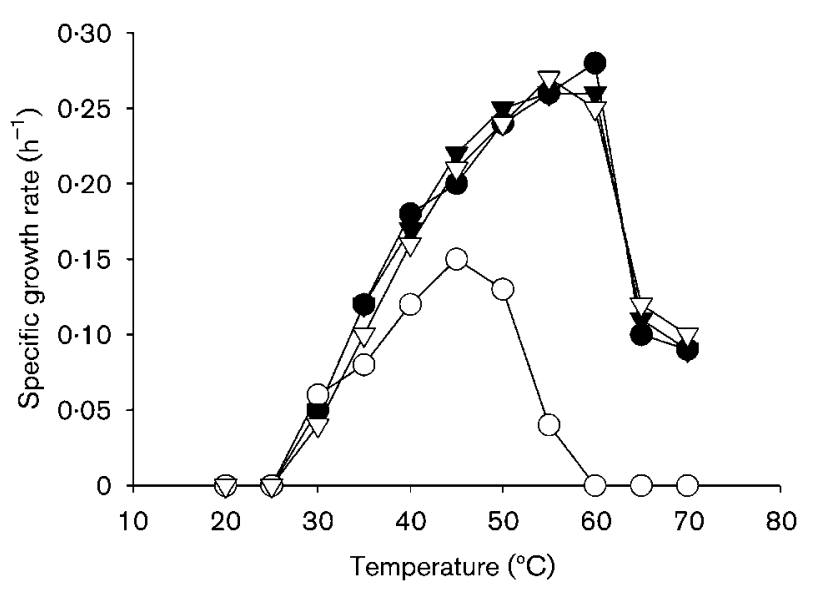

Fig. 1. Effect of temperature on the growth rates of isolates LS-286 $(\nabla)$ and LS-293 $^{\top}(\nabla), R$. radiotolerans DSM $5868^{\top}$ $(\bigcirc)$ and $R$. xylanophilus DSM $9441^{\top}(\bullet)$.

division were frequently observed and cells often grew in chains that were wrapped around each other, forming large aggregates. Images from scanning electron microscopy and atomic-force microscopy are available as Supplementary Fig. A in IJSEM Online.

Various media, including nutrient medium, trypticase-soy medium, Luria-Bertani medium, medium 162 (Degryse et al., 1978) and Thermus medium, were tested initially to determine whether they supported the growth of strains LS-286 and LS- $293^{\mathrm{T}}$. Both strains grew on all of the media tested, but grew particularly well on Thermus medium. Strains LS-286 and LS- $293^{\mathrm{T}}$ grew between 30 and $70^{\circ} \mathrm{C}$; the optimum growth temperature was $60^{\circ} \mathrm{C}$ in Thermus medium, which is similar to that for the thermophilic species R. xylanophilus DSM $9441^{\mathrm{T}}$ but different from that of the mesophilic species $R$. radiotolerans DSM $5868^{\mathrm{T}}$ (Fig. 1). Strains LS-286 and LS-293 ${ }^{\mathrm{T}}$ were assessed in Thermus medium over a broad range of $\mathrm{pH}$ values (pH 6-11): the optimum $\mathrm{pH}$ was 8.0 at the optimum growth temperature. The $\mathrm{NaCl}$ concentration for growth of strains CB-286 and CB- $293^{\mathrm{T}}$ was in the range $0-5 \%$ (w/v); strains of $R$. xylanophilus DSM $9441^{\mathrm{T}}$ and $R$. radiotolerans DSM $5868^{\mathrm{T}}$ exhibited the same ranges $(0-4 \%$, $\mathrm{w} / \mathrm{v}$ ) for growth (data for $\mathrm{pH}$ and salinity are available as Supplementary Fig. B in IJSEM Online). Strains LS- $293^{\mathrm{T}}$, LS-286 and other strains of the genus Rubrobacter shared various biochemical characteristics, including the hydrolysis of carbohydrate polymers and the utilization of single carbon sources. The main differences in biochemical characteristics were observed during the assimilation of single carbon sources. Two carbon sources, L-glutamine and L-serine, were utilized by strains LS- $293^{\mathrm{T}}$ and LS-286 but not by other strains of the genus Rubrobacter. The two isolated strains could also be distinguished by their utilization of L-rhamnose, L-asparagine and D-glucose.
Table 1 presents the biochemical characteristics of strains LS- $293^{\mathrm{T}}$, LS-286 and other Rubrobacter species.

The fatty acid profiles of strains LS- $293^{\mathrm{T}}$ and LS-286 were very similar under the same growth conditions. An internally branched fatty acid with a methyl group at position 14 , 14-methyl-18: 0 , was the major fatty acid $(33 \cdot 27 \%$ in strain LS- $293^{\mathrm{T}}$ and $31.44 \%$ in strain LS-286 at $60{ }^{\circ} \mathrm{C}$ ). Other branched fatty acids, with a methyl group at position 12 , including 12-methyl-16:0 (12.32\%) and 12-methyl-17:0 $(13 \cdot 25 \%)$, were also present in acryl fatty acids in strain LS- $293^{\mathrm{T}}$ at $60^{\circ} \mathrm{C}$. The main distinctive characteristic of the isolates was the large proportion of saturated fatty acid 19:0, which was not obtained in previously described profiles of $R$. xylanophilus DSM $9441^{\mathrm{T}}$ and $R$. radiotolerans DSM $5868^{\mathrm{T}}$. Fatty acid methyl esters are the common derivatives subjected to GC-MS analysis of fatty acids. In this study, several strong chromatographic peaks were not consistent with the equivalent lengths of the fatty acid methyl esters in the MIDI (Microbial ID) database. Alternative methods of identification, including GC-MS of fatty acid picolinyl esters, were employed to confirm the cellular fatty acid constituents (Harvey, 1982; Wait \& Hudson, 1985; Carreto et al., 1996). In the thermophilic bacterium Thermococcus roseum, 12-methyl-18:0 is the predominant fatty acid and other internally branched fatty acids are also present, but this bacterium belongs to the phylum Thermomicrobia and is not related to $R$. radiotolerans, R. xylanophilus or strains LS-286 and LS $-293^{\mathrm{T}}$ (Pond et al., 1986; Garrity \& Holt, 2001). Fatty acid profiles are available in Supplementary Table A in IJSEM Online.

Previous studies have identified strong resistance to gamma-radiation as a special characteristic of the genus Rubrobacter (Suzuki et al., 1988; Yoshinaka et al., 1973; Ferreira et al., 1999). The survival curves for resistance to gamma-radiation of the type strains of $R$. radiotolerans and $R$. xylanophilus and isolates LS-293 ${ }^{\mathrm{T}}$ and LS-286 are sigmoid. The shoulder doses of radiation (the dose required before the number of c.f.u. declines) of strains LS- $293^{\mathrm{T}}$ and LS-286 were 4.8 and $5.0 \mathrm{kGy}$, respectively. The doses required to reduce the number of viable units after the shoulder to $37 \%$ (the mean dose required to inactivate a single c.f.u. of the irradiated population) were approximately $9 \cdot 8$ and $10 \cdot 0 \mathrm{kGy}$, respectively. The shoulder doses for the isolates were between those of $R$. xylanophilus DSM $9441^{\mathrm{T}}(4 \cdot 0 \mathrm{kGy})$ and $R$. radiotolerans DSM $5868^{\mathrm{T}}$ $(5 \cdot 8 \mathrm{kGy})$, which were comparable to the shoulder dose of D. radiodurans DSM $12573^{\mathrm{T}}$. These results presented here clearly indicate that the novel thermophilic bacterial isolates LS-293 ${ }^{\mathrm{T}}$ and LS-286 were highly resistant to radiation (Fig. 2). Radiation-resistant bacterial strains including $D$. radiodurans, D. geothermalis, D. murrayi, $R$. radiotolerans and $R$. xylanophilus have exhibited variable radiation resistance in previous studies (Moseley, 1967; Moseley \& Mattingly, 1971; Moseley \& Evans, 1983; Ferreira et al., 1997; Suzuki et al., 1988; Yoshinaka et al., 1973; Carreto et al., 1996). Of these radiation-resistant bacteria, the 
Table 1. Biochemical features that distinguish strains of the genus Rubrobacter

+, Positive result or growth; -, negative result or no growth; w, weak result. All tested strains grew in medium containing $5 \%$ (w/v) $\mathrm{NaCl}$, hydrolysed gelatin and were cytochrome oxidase-, oxidase-, $\beta$-galactosidase- and $\beta$-glucosidase-positive. D-Cellobiose, D-raffinose, D-trehalose, D-arabinose, D-fructose, D-mannose, lactose, L-glutamate and pyruvate were utilized by all of the strains. All of the organisms were $\alpha$-galactosidase-negative and $\alpha$-glucosidase-negative. None of the strains hydrolysed starch, casein, cellulose or tributyrin and none utilized D-sorbitol.

\begin{tabular}{|c|c|c|c|c|}
\hline Characteristic & LS-293 ${ }^{T}$ & LS-286 & R. xylanophilus DSM $9441^{\mathrm{T}}$ & R. radiotolerans DSM $5868^{\mathrm{T}}$ \\
\hline Optimum growth $\left({ }^{\circ} \mathrm{C}\right)$ & 60 & 60 & 60 & 45 \\
\hline Aesculin & - & - & + & + \\
\hline Xylan & - & - & + & - \\
\hline DNA & + & + & - & - \\
\hline D-Mannitol & - & - & - & + \\
\hline D-Xylose & + & + & + & - \\
\hline Glycerol & - & - & - & + \\
\hline L-Rhamnose & - & + & + & + \\
\hline D-Galactose & + & + & + & - \\
\hline Ribitol & - & - & - & + \\
\hline Succinate & - & - & + & - \\
\hline L-Asparagine & + & - & + & + \\
\hline L-Glutamine & + & + & $\mathrm{W}$ & - \\
\hline L-Serine & + & + & - & - \\
\hline Menaquinone & MK-8 & MK-8 & MK-8 & MK-8 \\
\hline DNA $\mathrm{G}+\mathrm{C}$ content $(\mathrm{mol} \%)$ & $68 \cdot 5$ & $67 \cdot 9$ & $67 \cdot 6$ & $64 \cdot 9$ \\
\hline
\end{tabular}

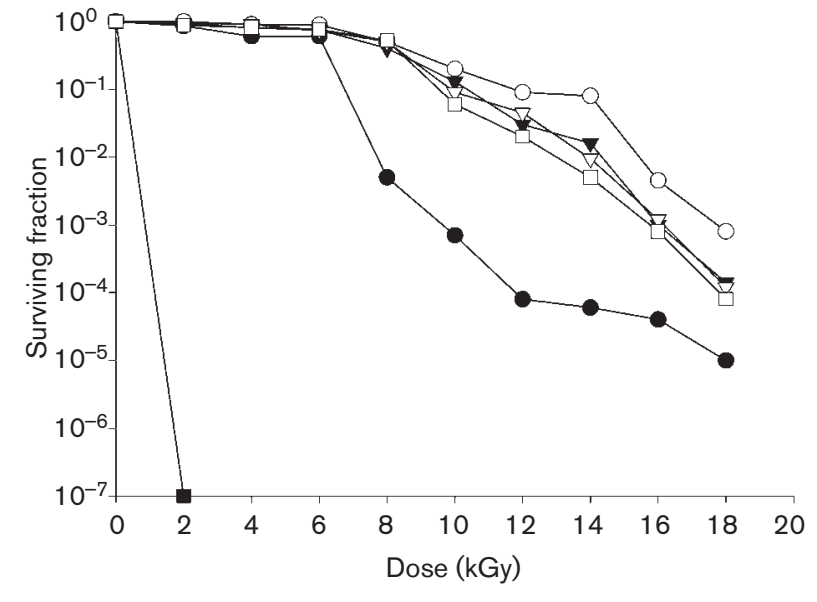

Fig. 2. Gamma-radiation survival curves of the new isolates and other radiation-resistant type strains. Strains: $\nabla$, LS-286; $\boldsymbol{\nabla}$, LS-293 ${ }^{\mathrm{T}} ; \bigcirc$, R. radiotolerans DSM $5868^{\mathrm{T}}$; ○, R. xylanophilus DSM $9441^{\top} ; \square$, D. radiodurans DSM $20539^{\top}$; $\mathbf{\square}$, E. coli $\mathrm{K}-12$. thermophilic species D. murrayi exhibited stronger resistance to gamma-radiation (shoulder doses, $7 \cdot 3 \mathrm{kGy}$ ) than did the well-known species $D$. radiodurans (shoulder doses, $5.0 \mathrm{kGy}$ ) and would be the most radiation-resistant bacterium currently known. Thus, isolates LS-293 ${ }^{\mathrm{T}}$ and LS-286 in this study also showed resistance to extreme gammaradiation. In previous studies, several mesophilic bacteria such as Acinetobacter radioresistens (Nishimura et al., 1988) and Methylobacterium radiotolerans (Green \& Bousfield, 1983) were identified as radiation-resistant, but very little information is known about the degrees of resistance or the mechanisms by which these organisms are resistant. Only those species in the genera Deinococcus and Rubrobacter with inherent radiation resistance have been studied in detail (Ferreira et al., 1997, 1999; Mattimore \& Battista, 1996; Sanders \& Maxcy, 1979; Suzuki et al., 1988; Yoshinaka et al., 1973). Of these extremely radiation-resistant bacteria, almost all are thermotolerant $(D$. radiodurans and $R$. radiotolerans) or thermophilic (D. murrayi, D. geothermalis and $R$. xylanophilus). It is not clear how these radiation-resistant bacteria acquire the ability to resist radiation damage, but further evidence has suggested that 
this capacity could be acquired by an evolutionary process resulting from environmental stress, especially drought and heat stress (Mattimore \& Battista, 1996). Drought and heat stress, in bacterial cells, would cause damage similar to that caused by gamma-irradiation. DNA oxidation or strand breakdown leads to the death of bacterial cells (Mattimore \& Battista, 1996; White et al., 1999). Geothermal areas, such as hot springs, are associated with environmental stressors such as drought and heat, and micro-organisms able to survive in these extreme environments could develop different mechanisms to combat the stress.

The DNA G + C content of isolate LS- $293^{\mathrm{T}}$ was $68.9 \mathrm{~mol} \%$ and that of LS-286 was $67.9 \mathrm{~mol} \%$, as determined by the HPLC method. This result reveals that LS- $293^{\mathrm{T}}$ and LS-286 are high-G + C, Gram-positive bacteria. Strains LS- $293^{\mathrm{T}}$ and LS-286 and all type strains of species of the genus Rubrobacter were tested using DNA-DNA hybridization to elucidate their interrelatedness. Strain LS- $293^{\mathrm{T}}$ showed $59 \cdot 6 \%$ relatedness to $R$. xylanophilus DSM $9441^{\mathrm{T}}$ and $42 \cdot 4 \%$ relatedness to $R$. radiotolerans DSM $5868^{\mathrm{T}}$. Strain LS- $286^{\mathrm{T}}$ showed $52 \cdot 8 \%$ relatedness to $R$. xylanophilus DSM $9441^{\mathrm{T}}$ and $46 \cdot 2 \%$ relatedness to $R$. radiotolerans DSM $5868^{\mathrm{T}}$. The relatedness between strains LS $-293^{\mathrm{T}}$ and LS-286 was $85 \cdot 7 \%$.

Following PCR amplification and sequencing, 16S rRNA gene sequences of $1476 \mathrm{nt}\left(\right.$ strain LS-293 ${ }^{\mathrm{T}}$ ) and $1475 \mathrm{nt}$ (strain LS-286) were determined. A comparison of the $16 \mathrm{~S}$ rRNA gene sequences of strains LS-293 ${ }^{\mathrm{T}}$ and LS-286 with reference sequence data in the EMBL database suggested that these two strains belonged to the genus Rubrobacter. A more detailed analysis, based on a dataset of least 1400 unambiguous nucleotides between positions 28 and 1526 (Escherichia coli numbering; Brosius et al., 1978), confirmed this result. Strains LS-293 ${ }^{\mathrm{T}}$ and LS-286, which have identical $16 \mathrm{~S}$ rRNA gene sequences at all positions, exhibited the highest mutual similarity $(99 \cdot 2 \%)$ and constituted a sister cluster next to R. xylanophilus DSM $9441^{\mathrm{T}}$. The similarities between the 16S rRNA gene sequence of the LS-293/LS286 cluster and those of $R$.xylanophilus and $R$. radiotolerans were $95 \cdot 1$ and $92 \cdot 4 \%$, respectively. Fig. 3 presents a $16 \mathrm{~S}$
rRNA gene sequence-based phylogenetic dendrogram generated by the neighbour-joining method (Saitou \& Nei, 1987).

On the basis of the results of phylogenetic analysis of the $16 \mathrm{~S}$ rRNA genes, DNA-DNA relatedness, biochemical features and fatty acid composition presented in this study, strains LS-286 and LS-293 ${ }^{\mathrm{T}}$ represent a novel species of the genus Rubrobacter. The name Rubrobacter taiwanensis sp. nov. is proposed.

\section{Description of Rubrobacter taiwanensis sp. nov.}

Rubrobacter taiwanensis (tai.wan.en'sis. N.L. masc. adj. taiwanensis of Taiwan, where the micro-organism was first isolated).

Colonies on Thermus medium incubated at $60^{\circ} \mathrm{C}$ for 7 days are $1 \cdot 6-2 \cdot 2 \mathrm{~mm}$ in diameter, circular, convex, smooth, opaque and light pink. Cells are aerobic, Grampositive, pleomorphic, short, rod-shaped or coccoid, $0 \cdot 9-$ $1.0 \mu \mathrm{m}$ wide and $1.0-3.0 \mu \mathrm{m}$ long. They do not exhibit flagella, motility or endospores. Thermophilic, with growth over the temperature range $30-70^{\circ} \mathrm{C}$, and the optimum temperature is $60^{\circ} \mathrm{C}$. The $\mathrm{pH}$ range for growth is $6-11$, with the optimum $\mathrm{pH}$ at about $\mathrm{pH} 8 \cdot 0$. The $\mathrm{G}+\mathrm{C}$ content of the DNA is $68.5 \mathrm{~mol} \%$. Cytochrome oxidase, catalase and $\beta$-galactosidase are present. Growth occurs in Thermus medium containing $5.0 \%(\mathrm{w} / \mathrm{v}) \mathrm{NaCl}$. Gelatin and DNA are hydrolysed. The strain can utilize numerous carbon sources, including D-cellobiose, D-fructose, D-galactose, D-glucose, D-mannose, maltose, D-melibiose, myo-inositol, D-raffinose, D-trehalose, D-xylose, lactose, L-arabinose, Lglutamine, L-glutamate, L-serine, L-proline and L-arginine. The predominant fatty acids are 14-methyl-18:0, 12methyl-17:0, 12-methyl-16:0 and 19:0. Strains LS-293 ${ }^{\mathrm{T}}$ and LS-286 are highly resistant to gamma-radiation.

The type strain $\mathrm{LS}-293^{\mathrm{T}} \quad\left(=\mathrm{ATCC}\right.$ BAA $-406^{\mathrm{T}}=\mathrm{BCRC}$ $17173^{\mathrm{T}}$ ) and the reference strain LS-286 (=ATCC BAA$452=$ BCRC 17198) were isolated from Lu-shan hot springs in Taiwan.

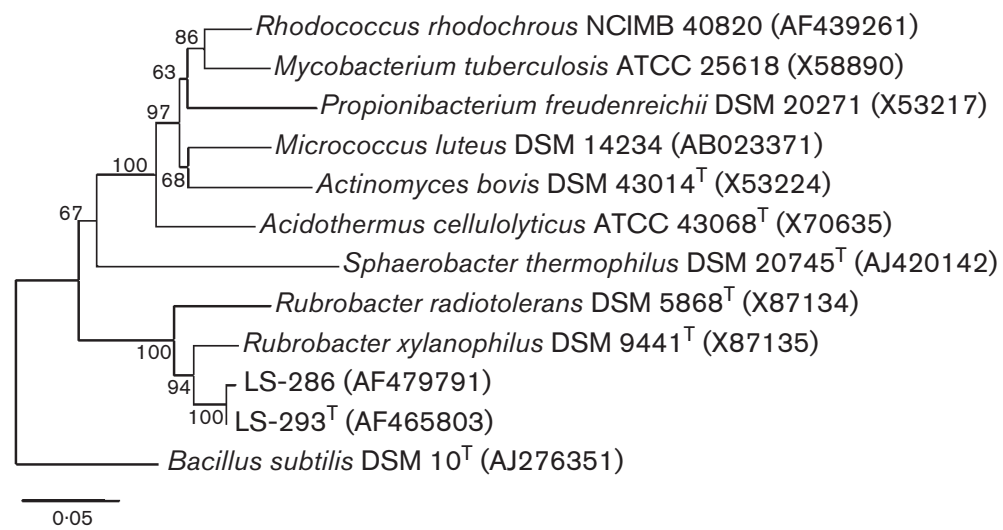

Fig. 3. Phylogenetic relationship dendrogram (based on pairwise 16S rRNA gene sequence comparisons) of the isolated strains LS-286 and LS-293' ${ }^{\top}$, type strains $R$. radiotolerans DSM $5868^{\top}$ and $R$. xylanophilus DSM $9441^{\top}$ and reference strains of Gram-positive phyla. Bootstrap values based on 1000 replications are listed as percentages at branching points. Bar, $5 \%$ evolutionary distance. 


\section{Acknowledgements}

The authors would like to thank the National Science Council of the Republic of China for financially supporting this research under contract no. NSC 92-2317-B-002-027. The authors also thank Dr C. Hu (Institute of Nuclear Energy Research, Atomic Energy Council) for assistance provided during gamma-irradiation. The authors are grateful to Professor L.-L. Huang, Dr S.-J. Chen, Miss C.-Y. Lin and Mr C.-Y. Tang (all of National Taiwan University) for electron microscopy. We are also indebted to Mr Y.-C. Wang and C.-C. Lin (Nanotake Technology Co. Ltd) for conducting the atomicforce microscopy.

\section{References}

Brosius, J., Palmer, M. L., Kennedy, P. J. \& Noller, H. F. (1978). Complete nucleotide sequence of a $16 \mathrm{~S}$ ribosomal RNA gene from Escherichia coli. Proc Natl Acad Sci U S A 75, 4801-4805.

Carreto, L., Moore, E., Nobre, M. F., Wait, R., Riley, P. W., Sharp, R. J. \& da Costa, M. S. (1996). Rubrobacter xylanophilus sp. nov., a new thermophilic species isolated from a thermally polluted effluent. Int J Syst Bacteriol 46, 460-465.

Chen, M.-Y., Lin, G.-H., Lin, Y.-T. \& Tsay, S.-S. (2002a). Meiothermus taiwanensis sp. nov., a novel filamentous, thermophilic species isolated in Taiwan. Int J Syst Evol Microbiol 52, 1647-1654.

Chen, M.-Y., Tsay, S.-S., Chen, K.-Y., Shi, Y.-C., Lin, Y.-T. \& Lin, G.-H. (2002b). Pseudoxanthomonas taiwanensis sp. nov., a novel thermophilic, $\mathrm{N}_{2} \mathrm{O}$-producing species isolated from hot springs. Int $J$ Syst Evol Microbiol 52, 2155-2161.

Chung, A. P., Rainey, F., Nobre, M. F., Burghardt, J. \& da Costa, M. S. (1997). Meiothermus cerbereus sp. nov., a new slightly thermophilic species with high levels of 3-hydroxy fatty acids. Int $J$ Syst Bacteriol 47, 1225-1230.

Degryse, E., Glansdorff, N. \& Pierard, A. (1978). A comparative analysis of extreme thermophilic bacteria belonging to the genus Thermus. Arch Microbiol 117, 189-196.

Ezaki, T., Hashimoto, Y. \& Yabuuchi, E. (1989). Fluorometric deoxyribonucleic acid-deoxyribonucleic acid hybridization in microdilution wells as an alternative to membrane filter hybridization in which radioisotopes are used to determine genetic relatedness among bacterial strains. Int J Syst Bacteriol 39, 224-229.

Ferreira, A. C., Nobre, M. F., Rainey, F. A., Silva, M. T., Wait, R., Burghardt, J., Chung, A. P. \& da Costa, M. S. (1997). Deinococcus geothermalis sp. nov. and Deinococcus murrayi sp. nov., two extremely radiation-resistant and slightly thermophilic species from hot springs. Int J Syst Bacteriol 47, 939-947.

Ferreira, A. C., Nobre, M. F., Moore, E., Rainey, F. A., Battista, J. R. $\&$ da Costa, M. S. (1999). Characterization and radiation resistance of new isolates of Rubrobacter radiotolerans and Rubrobacter xylanophilus. Extremophiles 3, 235-238.

Garrity, G. M. \& Holt, J. G. (2001). Phylum BVII. Thermomicrobia phy. nov. In Bergey's Manual of Systematic Bacteriology, 2nd edn, vol. 1, p. 447. Edited by D. R. Boone \& R. W. Castenholz. New York: Springer.

Green, P. N. \& Bousfield, I. J. (1983). Emendation of Methylobacterium Patt, Cole, and Hanson 1976; Methylobacterium rhodinum (Heumann 1962) comb. nov. corrig.; Methylobacterium radiotolerans (Ito and Iizuka 1971) comb. nov., corrig.; and Methylobacterium mesophilicum (Austin and Goodfellow 1979) comb. nov. Int J Syst Bacteriol 33, 875-877.

Hall, T. A. (1999). BioEdit: a user-friendly biological sequence alignment editor and analysis program for Windows 95/98/NT. Nucleic Acids Symp Ser 41, 95-98.
Hansma, H. G. \& Hoh, J. H. (1994). Biomolecular imaging with the atomic force microscope. Annu Rev Biophys Biomol Struct 23, 115-139.

Harvey, D. J. (1982). Picolinyl esters as derivatives for the structural determination of long chain branched and unsaturated fatty acids. Biomed Mass Spectrom 9, 33-38.

Jukes, T. H. \& Cantor, C. R. (1969). Evolution of protein molecules. In Mammalian Protein Metabolism, pp. 21-132. Edited by H. N. Munro. New York: Academic Press.

Kumar, S., Tamura, K., Jakobsen, I. B. \& Nei, M. (2001). MEGA2: molecular evolutionary genetics analysis software. Bioinformatics 17, $1244-1245$.

Kuykendall, L. D., Roy, M. A., O’Neill, J. J. \& Devine, T. E. (1988). Fatty acids, antibiotic resistance, and deoxyribonucleic acid homology groups of Bradyrhizobium japonicum. Int J Syst Bacteriol 38, 358-361.

Maidak, B. L., Larsen, N., McCaughey, M. J., Overbeek, R., Olsen, G. J., Fogel, K., Blandy, J. \& Woese, C. R. (1994). The Ribosomal Database Project. Nucleic Acids Res 22, 3485-3487.

Manaia, C. M. \& da Costa, M. S. (1991). Characterization of halotolerant Thermus isolates from shallow marine hot springs on S. Miguel, Azores. J Gen Microbiol 137, 2643-2648.

Mattimore, V. \& Battista, J. R. (1996). Radioresistance of Deinococcus radiodurans: functions necessary to survive ionizing radiation are also necessary to survive prolonged desiccation. J Bacteriol 178, 633-637.

Mesbah, M. \& Whitman, W. B. (1989). Measurement of deoxyguanosine/thymidine ratios in complex mixtures by high-performance liquid chromatography for determination of the mole percentage guanine + cytosine of DNA. J Chromatogr 479, 297-306.

Moseley, B. E. B. (1967). The isolation and some properties of radiation-sensitive mutants of Micrococcus radiodurans. J Gen Microbiol 49, 293-300.

Moseley, B. E. B. \& Evans, D. M. (1983). Isolation and properties of strains of Micrococcus (Deinococcus) radiodurans unable to excise ultraviolet light-induced pyrimidine dimers from DNA: evidence for two excision pathways. J Gen Microbiol 129, 2437-2445.

Moseley, B. E. \& Mattingly, A. (1971). Repair of irradiation transforming deoxyribonucleic acid in wild type and a radiationsensitive mutant of Micrococcus radiodurans. J Bacteriol 105, 976-983.

Nishimura, Y., Ino, T. \& lizuka, H. (1988). Acinetobacter radioresistens sp. nov. isolated from cotton and soil. Int J Syst Bacteriol 38, 209-211.

Pearson, W. R. \& Lipman, D. J. (1988). Improved tools for biological sequence comparison. Proc Natl Acad Sci U S A 85, 2444-2448.

Pond, J. L., Langworthy, T. A. \& Holzer, G. (1986). Long-chain diols: a new class of membrane lipids from a thermophilic bacterium. Science 231, 1134-1136.

Rainey, F. A., Ward-Rainey, N., Kroppenstedt, R. M. \& Stackebrandt, E. (1996). The genus Nocardiopsis represents a phylogenetically coherent taxon and a distinct actinomycete lineage: proposal of Nocardiopsaceae fam. nov. Int J Syst Bacteriol 46, 1088-1092.

Saitou, N. \& Nei, M. (1987). The neighbor-joining method: a new method for reconstructing phylogenetic trees. Mol Biol Evol 4, 406-425.

Sanders, S. W. \& Maxcy, R. B. (1979). Patterns of cell division, DNA base compositions, and fine structures of some radiation-resistant vegetative bacteria found in food. Appl Environ Microbiol 37, 159-168.

Santos, M. A., Williams, R. A. D. \& da Costa, M. S. (1989). Numerical taxonomy of Thermus isolates from hot springs in Portugal. Syst Appl Microbiol 12, 310-315.

Suzuki, K., Collins, M. D., lijima, E. \& Komagata, K. (1988). Chemotaxonomic characterization of a radiotolerant bacterium 
Arthrobacter radiotolerans: description of Rubrobacter radiotolerans gen. nov., comb. nov. FEMS Microbiol Lett 52, 33-40.

Tenreiro, S., Nobre, M. F. \& da Costa, M. S. (1995). Thermus silvanus sp. nov. and Thermus chliarophilus sp. nov., two new species related to Thermus ruber but with lower growth temperatures. Int J Syst Bacteriol 45, 633-639.

Thompson, J. D., Higgins, D. G. \& Gibson, T. J. (1994). CLUSTAL W: improving the sensitivity of progressive multiple sequence alignment through sequence weighting, position-specific gap penalties and weight matrix choice. Nucleic Acids Res 22, 4673-4680.

Wait, R. \& Hudson, M. J. (1985). The use of picolinyl esters for the characterization of microbial lipids; application to Campylobacter species. Lett Appl Microbiol 1, 95-99.
White, O., Eisen, J. A., Heidelberg, J. F. \& 22 other authors (1999). Genome sequence of the radioresistant bacterium Deinococcus radiodurans R1. Science 286, 1571-1577.

Willems, A., Doignon-Bourcier, F., Goris, J., Coopman, R., de Lajudie, P., De Vos, P. \& Gillis, M. (2001). DNA-DNA hybridization study of Bradyrhizobium strains. Int $J$ Syst Evol Microbiol 51, 1315-1322.

Williams, R. A. D. \& da Costa, M. S. (1992). The genus Thermus and related microorganisms. In The Prokaryotes, pp. 3745-3753. Edited by A. Balows, H. G. Trüper, M. Dworkin, W. Harder \& K. H. Schleifer. New York: Springer.

Yoshinaka, T., Yano, K. \& Yanaguchi, H. (1973). Isolation of a highly radioresistant bacterium, Arthrobacter radiotolerans nov. sp. Agric Biol Chem 37, 2269-2275. 